\title{
Floriculture New Crop Update - Report from California Pack Trials 2003 1
}

\section{Dr. Rick Schoellhorn and Alexis A. Richardson ${ }^{2}$}

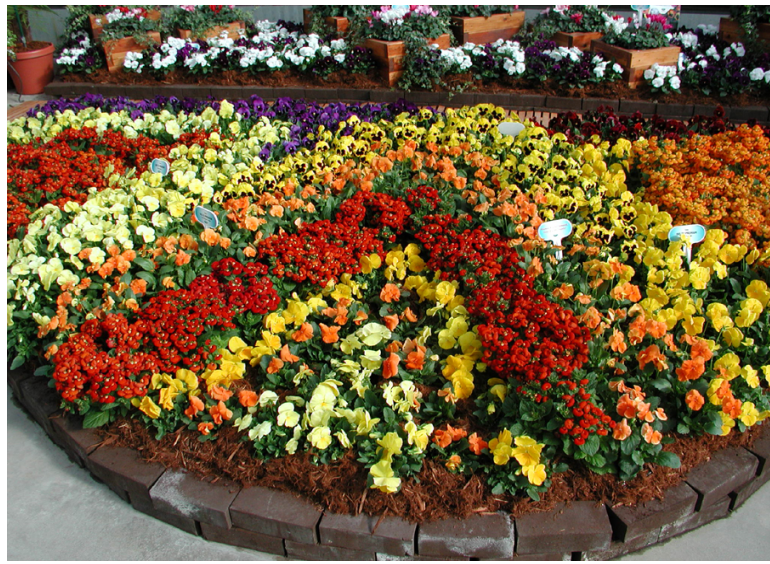

Figure 1. Pack trials displayed in California, 2003, highlighting new introduction in pansies and violas. The pack trials are the floriculture industry's week long celebration of all the new cultivars released on the market for the upcoming year.

Pack trials are industry events held in early April each year highlighting the new releases in flowering crops for each year. This is an industry event and, generally, not open to the public. Most of the exhibiting companies are not familiar names to the average consumer because by the time the plant is sold at a retail nursery it is tagged by the nursery that produces it, not by the breeder company that created or released the plant. For that reason consumers should use the name of the plant when looking to buy plants listed here, while nurseries should contact their distributors and use the company name to get the correct source.

Floranova had a great seed release that I couldn't help but stop at. It was Nicotiana 'Tinkerbell,' and it is a large hybrid. 'Tinkerbell' has rose-tinted petals with a green outer covering on 3- to 4-foot plants with a widely branched flower habit. This is one for the back of the perennial bed, but it is really striking.

At Ball FloraPlant, I was glad to see the introduction of 'Whisper White' to their 'Whisper' diascia line. We just finished our winter trials of diascia, and some of the 'Whisper' series were among our top selections. The 'Whisper' diascia are some of the most vigorous selections on the market and have a big blowsy habit, which makes them perfect for hanging basket production, and landscape use.

'Pink Angelonia' has apparently been very difficult to keep good stock for, so I was glad to see that it hadn't totally disappeared from the market. The 'Caritas Pink' is a bit smaller in stature than some of

1. This document is ENH899, one of a series of the Environmental Horticulture Department, Florida Cooperative Extension Service, Institute of Food and Agricultural Sciences, University of Florida. Original publication date May 16, 2005. Please visit the EDIS web site at http://edis.ifas.ufl.edu.

2. Rick Shoellhorn, associate professor, commercial floriculure specialist; Alexis A. Richardson, contributing writer; Environmental Horticulture Department, Institute of Food and Agricultural Sciences, University of Florida, Gainesville FL 32611.

The Institute of Food and Agricultural Sciences (IFAS) is an Equal Opportunity Institution authorized to provide research, educational information and other services only to individuals and institutions that function with non-discrimination with respect to race, creed, color, religion, age, disability, sex, sexual orientation, marital status, national origin, political opinions or affiliations. U.S. Department of Agriculture, Cooperative Extension Service, University of Florida, IFAS, Florida A. \& M. University Cooperative Extension Program, and Boards of County Commissioners Cooperating. Larry Arrington, Dean 


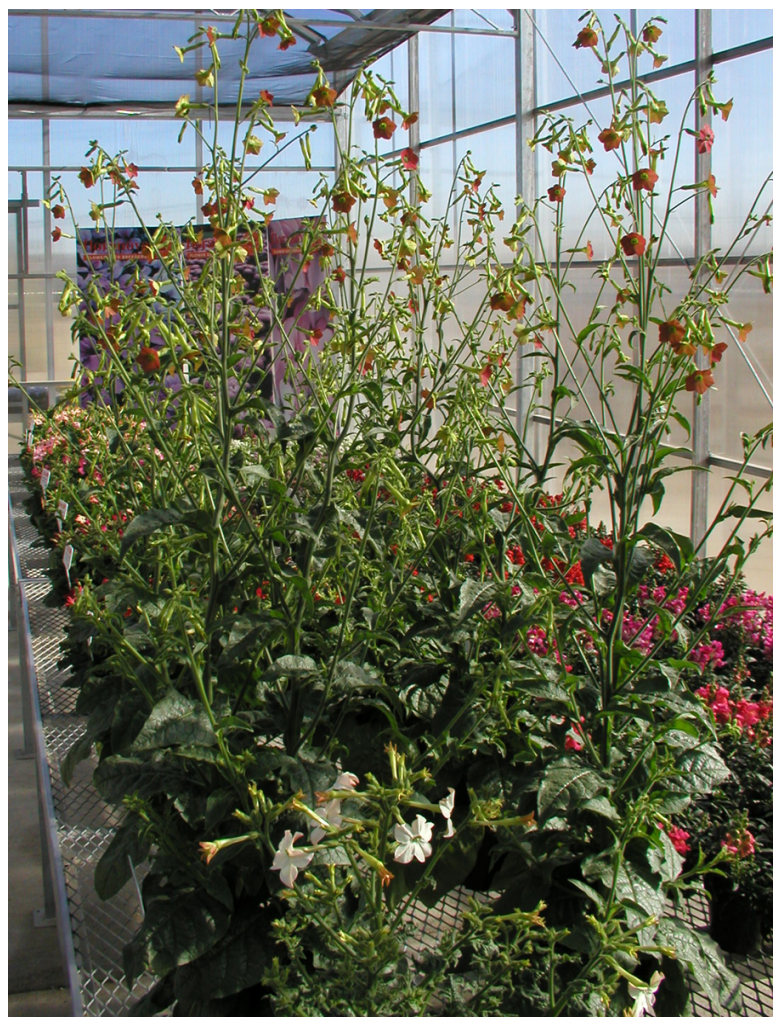

Figure 2. Nicotiana 'Tinkerbell' provides a very different look from that of traditional Nicotiana. The crop is much larger in stature and would make a good spring specialty gallon product and provide height to mixtures.

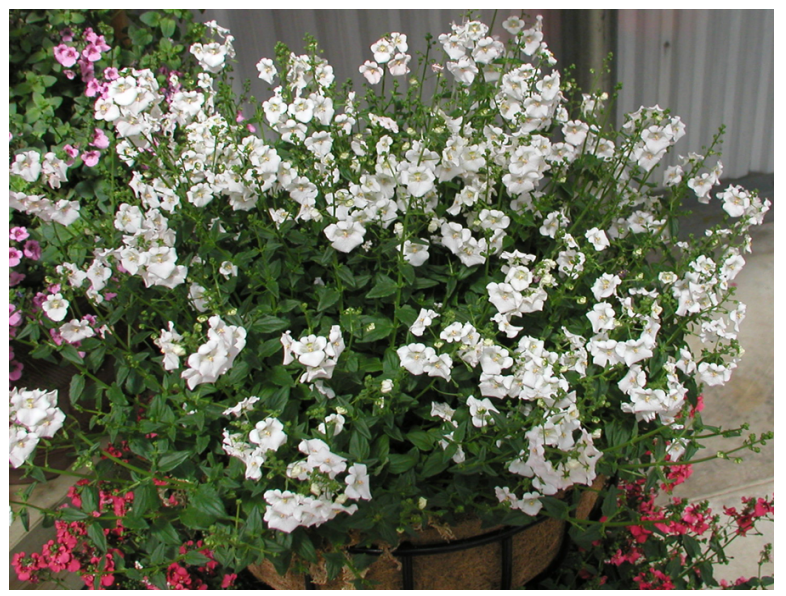

Figure 3. Ball FloraPlant's new 'Whisper White' diascia is a new color in the vigorous 'Whisper' series.

the other series on the market, but if you are looking for pink, it may be the only game in town anymore.

\section{Goldsmith Seed also had their line of Primula} obconica (The 'Libre' Series) out, and I think this group of Primula is really making a comeback. A lot of smaller growers have taken it up as a winter crop and are marketing the large-flowered hybrids as premium flowering potted plants that have a higher

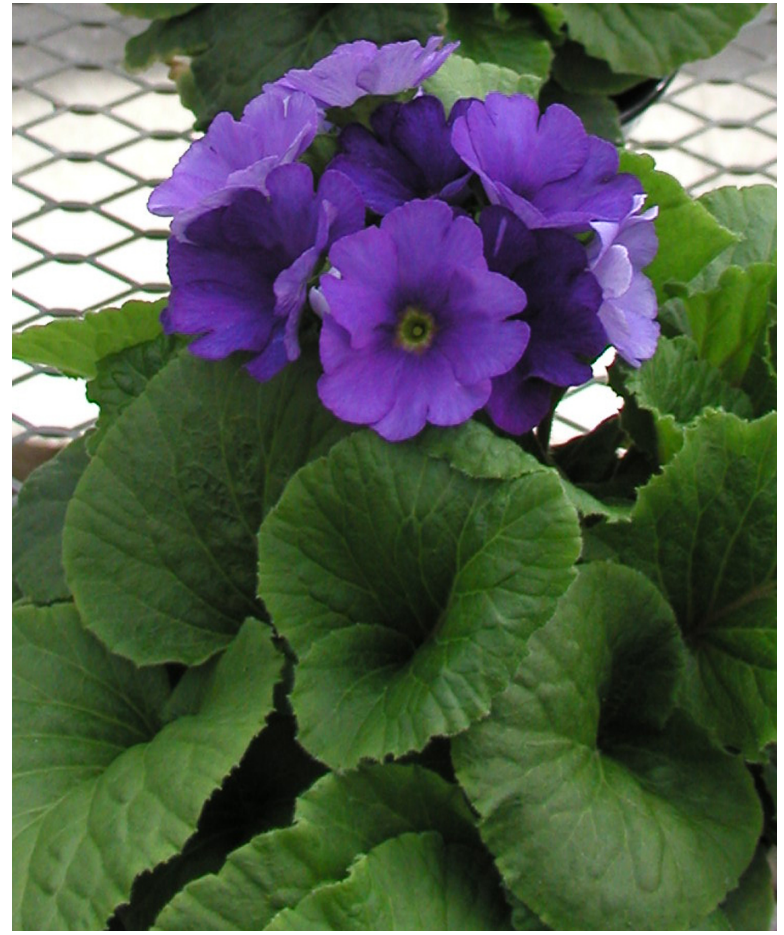

Figure 4. The 'Libre' series of primrose offers Florida growers a great alternative winter crop with a high dollar return. The plants are cold tolerant and long flowering. Primula obconica can be found from a variety of suppliers, and is definitely a crop worth looking into for extending your winter season.

heat tolerance than many other forms of Primula and good cold tolerance for winter plantings in the sunbelt. The 'Libre Fuchsia' and 'Deep Blue' were both striking and this is a crop that needs more attention, especially for growers looking into the early spring and fall extension markets.

One of the best stops is all this year was at Pacific Plug and Liner (PPL). PPL had great displays, some good production trials, and a lot of weird plants to make it more interesting. The crop that I was really glad to see in their lineup was Phygelius. Phygelius hybrids have been popular in England for a long time but are beginning to leak out into the American market and they have tons of potential. Think of them as a combination between a foxglove and a fuchsia. They are somewhat rangy (but respond well to PGRs) with deep green foliage, and terminal spikes of trumpet-shaped flowers with yellow throats and a variety of colors. These plants are strong perennial performers in the northwest and southern US. They also have a good specialty annual market in the central and northern US. We are looking into this 


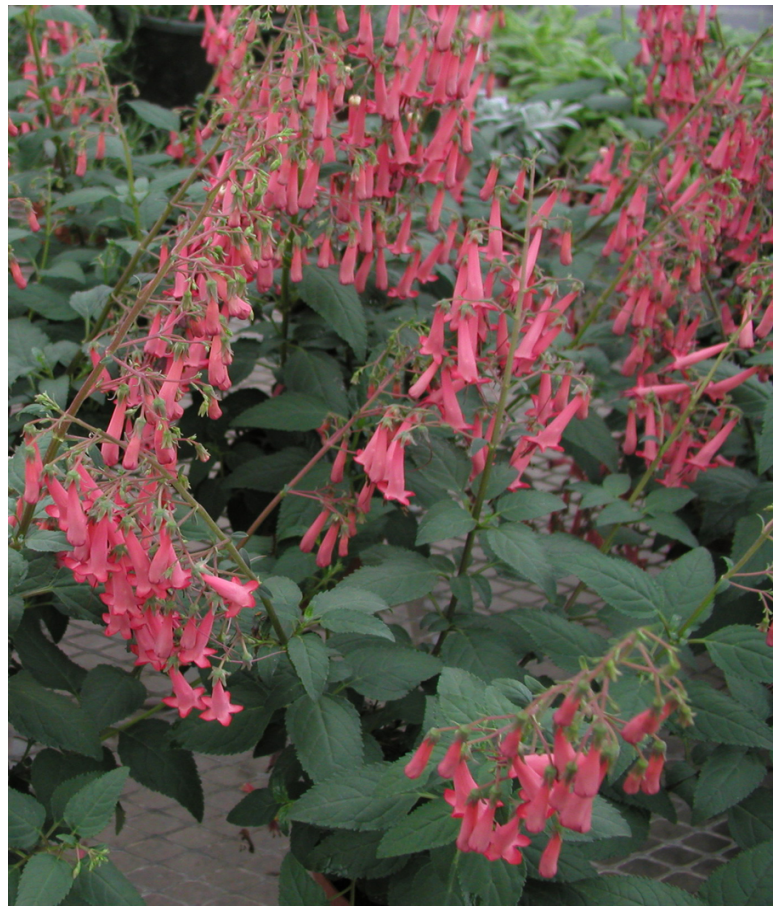

Figure 5. Phygelius 'Devil's Tears' has potential for use as a replacement for fuchsia in Florida. The plant exhibits good heat tolerance and has potential for new colors. It has much less disease sensitivity than fuchsia, but looks similar.

crop at the University of Florida as a potential fuchsia replacement for those of us unlucky enough to live in locations where fuchsia does not thrive. Pacific Plug and Liner had two cultivars from Carmel on display. 'Yellow Trumpet' and 'Devil's Tears,' a deep red hybrid with a more open flower form. But be on the lookout for other strong Phygelius as well.

'Sensation' and 'New Sensation' are both deep rich purple violet tones, 'Trewidden Pink' is a rich pink with yellow throat, and there are numerous others scattered through the fringe market as well.

Among the other cool plants at Pacific Plug and Liner was the 'Corsage' series of double verbena. Yes, you read right: double verbena. Pretty neat! From Cohen Propagation Nurseries two colors, peach and red, were really a great change in verbena. Each flower head had from semi-double to double florets, and while the difference was not apparent from a distance, it made for a great novelty once you were close to the plants. Production requirements are the same as for any verbena and this would make a great addition to a novelty line for any retailer.

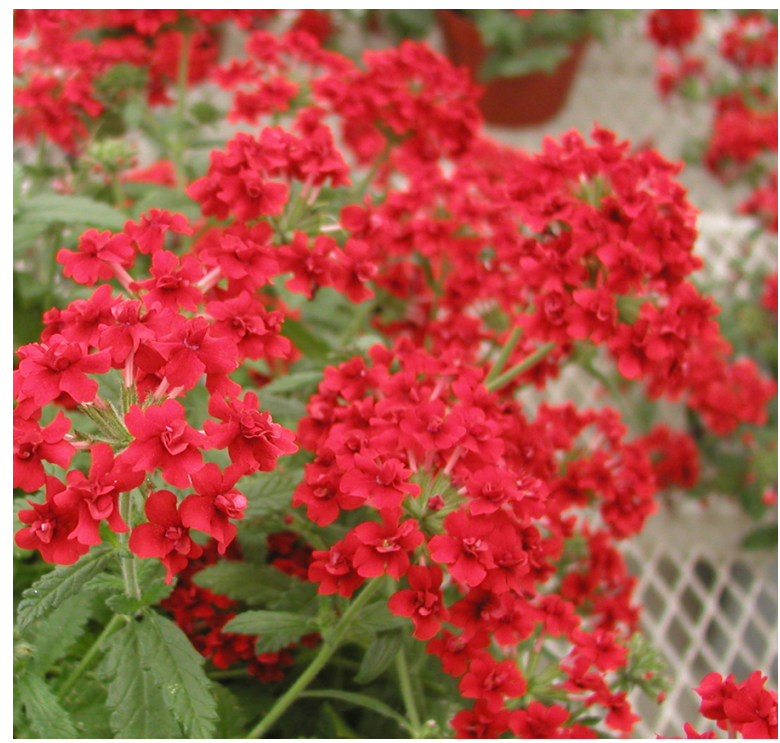

Figure 6. The 'Corsage' series of Verbena from Cohen Propagators boasts double florets and good growth habit. The plant is available as rooted or unrooted cuttings.

\section{Resources}

Pacific plug and Liner: www.ppandl.com

Goldsmith Seed: www.goldsmithseeds.com

Ball FloraPlant: www.ballfloraplant.com

Floranova: www.floranova.co.uk

Environmental Horticulture Department, University of Florida: http://hort.ifas.ufl.edu

Statewide Trialing Website: http://hort.ifas.ufl.edu/floriculture/ statewide_plant.htm 